\title{
Acute Fatty Liver of Pregnancy: A Life Threatening Condition
}

\author{
Sarita Sitaula, Ajay Agrawal, Achala Thakur, Tara Manandhar, Babauram Dixit Thapa, Jibanath Dhamala \\ Department of Obstetrics and Gynecology, BPKIHS, Dharan, Nepal
}

Received: December 4, 2019

Accepted: May 5, 2020

\begin{abstract}
Acute Fatty Liver of Pregnancy (AFLP) is a rare but catastrophic disease affecting women in pregnancy. It usually occurs in the third trimester or post-partum period. Delay in diagnosis is associated with morbid complications with high morbidity and mortality. We report a case of 24 years old female at 38 weeks period of gestation who presented with jaundice, vomiting for 3 days and deranged liver function test. She was diagnosed as acute fatty liver of pregnancy and was delivered by instrumental delivery but required cesarean hysterectomy due to postpartum hemorrhage. She started improving with supportive care and discharged after 4 weeks of hospital stay.
\end{abstract}

Key words: AFLP, Hysterectomy, Postpartum hemorrhage

Citation : Sitaula S, Agrawal A, Thakur A, Manandhar T, Thapa BD, Dhamala J. Acute Fatty Liver of Pregnancy: A Life Threatening Condition. Nep J Obstet Gynecol. 2020;15(30):79-80. DOI: 10.3126/njog.v15i1.29348

\section{INTRODUCTION}

Acute fatty liver of pregnancy complicate 5-30 per 100,000 pregnancies. ${ }^{1}$ It is mostly seen in third trimester and persistent nausea, vomiting and jaundice are usual complaints. There would be varying degree of liver dysfunction, coagulation failure and recurrent hypoglycemia. Serum bilirubin usually are $<10 \mathrm{mg} / \mathrm{dl}$ and serum aminotransferease level $<1000 \mathrm{U} / 1 .^{2}$ AFLP usually worsens after diagnosis and starts improving after few days of delivery. Maternal mortality rate is estimated to be $12.5-18 \%$ with neonatal mortality rate of $7-66 \%{ }^{3}$ With supportive care, recovery usually is complete.

\section{CASE}

A 24 years primigravida at 38 weeks period of gestation was referred-in from peripheral hospital on 19 September 2018 to BP Koirala Institute of Health Sciences with complaints of vomiting and jaundice for 3 days. There was no history of abdominal pain, vaginal bleeding, leaking nor hypertension. She perceived fetal movement adequately. There was no significant past history.

On examination patient was conscious, and oriented to time, place and person. She was icteric, and mild pedal edema was present. Her blood pressure was 140/80 $\mathrm{mmHg}$ and pulse rate 84 beats/min.Cardiovascular

\section{CORRESPONDENCE}

Dr Sarita Sitaula

Department of Obstetrics and Gynecology, BPKIHS, Dharan

Email: dr.sarita.sitaula@gmail.com; Mobile: +977-9842052514 and respiratory examination was normal. Abdominal examination showed single live term fetus in cephalic presentation and vaginal examination showed closed cervix and uneffaced. There was deranged liver function test, low blood sugar level and metabolic acidosis during admission [Table-1].

Table-1: Blood parameters at the time of admission

\begin{tabular}{|l|l|}
\hline Parameter at admission & Lab value \\
\hline Hemoglobin & $11.6 \mathrm{gm} / \mathrm{dl}$ \\
\hline Total Leucocyte count & $22900 / \mathrm{cm} 3$ \\
\hline Platelet & $214000 / \mathrm{cm} 3$ \\
\hline Urea/ Creatinine & $33 / 1.9 \mathrm{mg} / \mathrm{dl}$ \\
\hline AST/ALT/ALP & $285 / 310 / 1243 \mathrm{IU} / \mathrm{L}$ \\
\hline Total/ conjugated bilirubin & $4.6 / 2.5 \mathrm{mg} / \mathrm{dl}$ \\
\hline Total protein/albumin & $6.8 / 3.6 \mathrm{mg} / \mathrm{dl}$ \\
\hline PT/INR & $30 \mathrm{sec} / 3.12$ \\
\hline RBS & $36 \mathrm{mg} / \mathrm{dl}$ \\
\hline Viral markers (Hep A,B,C,E) & Negative \\
\hline Urine RE/ME & Albumin- trace \\
\hline ABG & Metabolic acidosis \\
\hline
\end{tabular}

Patient had multiple episode of hypoglycemia. AFLP was diagnosed and supportive care was given in intensive care unit. Patient went on spontaneous labor and delivered on $3^{\text {rd }}$ day of admission by 
instrumental delivery for fetal bradycardia in $2^{\text {nd }}$ stage of labor. The fetal outcome was stillbirth of a male baby. Patient developed primary postpartum hemorrhage and was managed medically as well as with balloon tamponade and blood products. Peripartum hysterectomy was done on $2^{\text {nd }}$ postpartum day for uncontrolled postpartum hemorrhage and was kept on ventilator for 8 days. Patient received 16 units of fresh blood, 20 pint of fresh frozen plasma, 1 pint packed cell volume, 10 pint of platelet rich plasma and 8 units of cryoprecipitate.

Patient had burst abdomen which was managed with bogota dressing and wound healing was by secondary intention. Patient was discharged after 28 days of hospital stay. Patient was followed up after 6 months and found that she was doing well.

\section{COMMENTS}

The pathogenesis of AFLP is unclear, but defects in fatty acid metabolism play a role. Free fatty acids normally increase in pregnancy, particularly late in gestation, to fuel fetoplacental growth and development. If maternal-fetal fatty acid metabolism is defective, intermediate products of metabolism can accumulate in maternal blood and hepatocytes, with deleterious effects on maternal hepatocytes. ${ }^{4}$ Proposed risk factors in developing AFLP include primiparity, pregnancy with a male fetus, multiple gestations, advanced maternal age, and low body mass index of the mother. ${ }^{5}$

Pregnancy with jaundice has many differential diagnoses but AFLP was diagnosed according to swansea criteriawhich is collection of symptoms, signs, biochemical and imaging findings where presence of six or more findings in the absence of other causes establish a clinical diagnosis of ALFP [Table 2]. ${ }^{6}$
Table-2: Swansea criteria for the diagnosis of AFLP

\begin{tabular}{|l|l|}
\hline Clinical features & $\begin{array}{l}\text { Vomiting } \\
\text { Abdominal pain } \\
\text { Polydipsia/ polyuria } \\
\text { Encephalopathy }\end{array}$ \\
\hline Hepatic function & $\begin{array}{l}\text { Bilirubin }>14 \mu \mathrm{mol} / 1 \\
\text { AST/ALT }>42 \mathrm{IU} / \mathrm{L} \\
\text { Ammonia }>47 \mu \mathrm{mol} / 1\end{array}$ \\
\hline Renal function & $\begin{array}{l}\text { Urea }>340 \mu \mathrm{mol} / 1 \\
\text { Creatinine }>150 \mu \mathrm{mol} / 1\end{array}$ \\
\hline Endocrine function & Glucose $<4 \mathrm{mmol} / 1$ \\
\hline Hematological value & $\begin{array}{l}\text { Leukocytosis }>11 \times 109 / 1 \\
\text { Coagulopathy } \mathrm{PT}>14 \mathrm{sec} \text { or APTT }>34 \mathrm{sec} \\
\text { (often platelet count }>100 \times 1012 / 1\end{array}$ \\
\hline Radiological signs & USG: bright liver echo texture/ascites \\
\hline $\begin{array}{l}\text { Histological : liver } \\
\text { biopsy }\end{array}$ & Micro vesicular steatosis \\
\hline
\end{tabular}

In our case she presented with vomiting, jaundice and malaise; and investigation showed coagulopathy, acute kidney injury, raised bilirubin, raised transaminase, leukocytois, recurrent hypoglycemia and patient was normotensive so diagnosis of AFLP was favored.Though prompt diagnosis and delivery is the mainstay of management and which can improve both maternal and fetal outcome, in our case we delivered the baby after 2 days of admission due to delay in diagnosis of the condition. Patient was planned for cesarean section at admission due to nonreactive fetal tracing but it was postponed due to coagulation failure and started with blood products to correct the abnormality.

\section{CONCLUSIONS}

AFLP usually presents in $3^{\text {rd }}$ trimester or in early postpartum period. This is a life threatening complications of pregnancy which required prompt diagnosis, early delivery and supportive care to improve the perinatal as well as maternal outcome.

\section{REFERENCES}

1. Lamprecht A, Morton A, Laurie J, Lee W. Acute fatty liver of pregnancy and concomitant medical conditions: A review of cases at a quaternary obstetric hospital. Obstet Med. 2018;11:178-81.

2. Cunningham FG, Leveno KJ, Bloom SL, Dashe JS, Hoffman BL, Casey BM, et al. Williams Obstetrics. 25th ed. USA: McGraw Hill; 2018.

3. Rajasri AG, Shrestha R, Mitchell J. Acute fatty liver of pregnancy (AFLP) - An overview. J Obstet Gynaecol. 2007;27(3):237-40
4. Ibdah JA, Bennett MJ, Rinaldo P, Zhao Y, Gibson B Sims HF, et al. A fetal fatty-acid oxidation disorder as a cause of liver disease in pregnant women. N Engl J Med. 1999;340(22):1723-31.

5. Ablett J, Ashcroft A. Maternity Guidelines- Acute Fatty Liver of Pregnancy. 2018;1-5.

6. Joshi D, James A, Quaglia A, Westbrook RH, Heneghan MA. Liver disease in pregnancy. Lancet. 2010;375:594-605. 